\title{
The Study of Culture Shock Phenomenon of Indonesian Students That Came Back After Living Abroad (A Case Study of Indonesian Students Studying in Taiwan)
}

\author{
Claudia Phillo ${ }^{1}$ Eko Harry Susanto ${ }^{1 *}$
}

\author{
${ }^{1}$ Faculty of Communication, Tarumanagara University, Jakarta 11440, Indonesia \\ *Corresponding author. Email: ekos@fikom.untar.ac.id
}

\begin{abstract}
With developments in the transportation aspect, many Indonesian students have finally decided to study abroad. And aftet they lived abroad for awhile, they will get used to the culture and customs that exist in that country, and this will cause them to experience a culture shock phenomenon when they have to return to Indonesia. Taiwan is one of the countries that is quite attractive to Indonesian students to become a place for them to migrate to study. This study aims to find out the differences and problems felt by students who have returned to Indonesia, and to find out what methods can be used to adapt to a culture. This research was conducted using a qualitative method, in which the researcher conducted interviews with seven sources. The end result of this research itself illustrates the importance of intercultural communication and technology for a person in adapting to a culture
\end{abstract}

\section{Keywords: Acculturation Theory, Communication, Culture, Culture Shock Theory, Indonesian Culture, Taiwan}

\section{INTRODUCTION}

Nowadays, air transportation is very developed. This highly developed transportation allows people to efficiently move from one place to another. Thus the decrease in distance limitation between countries, causes many individuals to try to learn foreign languages, which in turn makes many students migrate to other countries.

On the other hand, Taiwan is one of the countries that chosen by many Indonesian students to study. In fact, Director of Education Division of Taipei Economic and Trade Office (TETO), Grace Ou, stated that in 2018 there were 7,000 Indonesian students coming to Taiwan to study. This number has increased when compared to 2016, where there were only 4,774 Indonesian students studying in Taiwan. Out of all the international students residing in Taiwan, Indonesia has the fourth most number of students studying in Taiwan, after China, Malaysia, and Vietnam. Going and settling in another country absolutely was not an easy thing. They need to try to adapt in new invorinment. They will slowly get used to the new culture after repeadly seen, felt, and even praticed the culture. Communication itself is an aspect that is quite worrying and becomes a difficulty for individuals who will enter into a new culture. When students are studying overseas, they obviously will learn things related to the country, so that they will slowly begin to get used to and become part of the culture of the country itself [1]. When a student who travel overseas and into a new culture, those students will keep interacting with the culture of the country. Therefore, the culture will stick and turn into the students' habit. And when it happens, of course it will be hard for the students to get back being used to the culture of their own countries. In a book written by Susanto stated that humans are creatures which can't be separated from the act of communicating, each thing done by someone may create meaning, interacting with someone else is a necessity for every human [2].

When a student who has already stayed overseas for years finally get back to Indonesia, he will face back Indonesia's culture. This will usually make him face the phenomenon of culture shock, because he is used to or even become part of the culture where he studies. Fatimah had ever stated that in our lives among society, there will be a process of influencing one another, continuously and alternately, and from that process will appear or born a new culture pattern and social behavior [3]. A student who gets back to his hometown after living in a foreign culture for a long time will face the phenomenon of culture shock, but the difference here is they will struggle to adapt with his original culture that he has before.

The research itself aims to find out what are the differences felt by students who have just returned from Taiwan. The differences which they feel will certainly cause them to have various difficulties to adapt to the cultures or customs in Indonesia. We will also discuss more on the effective ways applied by them which help them to adapt with Indonesia's culture. 
The authors (researchers) hope that this research can be useful to readers. So that this research can help individuals who may be experiencing cultural shock. The authors also hope that this research can be used as a reference for other researchers in completing their work.

\subsection{Related Work}

Below are some previous researches which become the references for this research:

\subsubsection{Phenomenology Study of Sumatran Students' Cultural Shock in Untirta}

This journal was written by Ayu Siti Rachma from the Faculty of Social and Political Sciences Universitas Sultan Ageng Tirtayasa Serang in 2016. This research discusses about how students from Sumatera face the phenomenon of culture shock while continuing their study at Untirta. The results found that students have expectations while traveling out of town. But unfortunately, they experienced disappointment that resulted them suffering a cultural shock. To overcome their problem, they fill their daily activities by following the organization both inside and outside their campus [4].

\subsubsection{Case Study of Papuan Affirmation Student's Culture Shock at Pendidikan Indonesia University}

This research was written by Rini Andriani Rohma in 2016. Rini herself was one of is one of the students of Communication Science Department at the Faculty of Social Sciences Education at Pendidikan Indonesia University. In this study, researchers examined on how the intercultural competence of Papuan affirmation students in dealing with cultural shock at the Pendidikan Indonesia University Bandung. The results showed that the biggest challenge for Papuan affirmation students is Bandung's social environment which is still not open. However, it is not an obstacle for Papuan and indigenous students to interact. However, Papuan students still feel more comfortable when hanging out or interacting with fellow Papuan students [5].

\subsubsection{Communication Barriers and Cultural Shock of South Koreans Living in Indonesia}

This research was written by Jessica Lestari and Sinta Paramita in 2019. Journal of Communication Sciences from Tarumanegara University discusses how communication barriers and cultural shock are experienced by South Koreans when they have to live in Indonesia. The results found out that communication barriers caused cultural shock in South Koreans living in Indonesia, and language was the main cause. In addition, differences in appetite, transportation, habits, religion, and geography are also other factors that cause cultural shock [6].

\subsubsection{Inter-Cultural Adaptation Theories}

This research was written by Lusia Savitri Setyo Utami in 2015. Journal of Communication Sciences from Universitas Tarumanagara discusses how various theories of adaptation among cultures are implemented in communication patterns, when one adapts mainly from a different culture. From this research we can see that each individual has the ability to conduct intercultural communication. So they will adapt by themselves to make them comfortable. But an intercultural adaptation is achieved when each individual, both immigrant and local, accepts each others' culture [7].

\subsection{Our Contribution}

This paper presents the results of research that has been conducted by researchers on the phenomenon of cultural shock that experienced by Indonesian students who have studied in Taiwan. The purpose of this research itself is to find out what are the cultural differences between Indonesia and Taiwan. Besides, this research also wanted to find out what are the difficulties that experienced by the students when they try to adapt with their original culture. Researchers hope that through this study people can understand what is culture shock and how to get through it.

\subsection{Paper Structure}

The paper is structured in 5 sections. Section $\mathbf{1}$ is an introduction to the problems in research. Section 2 various theories that used by researcher for this study. Section $\mathbf{3}$ is a brief description of the methods the researcher uses in determining, collecting, and processing research data for this study. Section 4 is the result of research that has been conducted by researchers. In section 5 the author draws an overall conclusion regarding the study. Last, was references included in this paper.

\section{BACKGROUND}

\subsection{Communication}

Liliweri states that communication is something essential, a human being is unlikely not to communicate [8]. According to Susanto communication is a process of transmission or transfer of understanding, whereas through this process we can connect an entity with another entity. Communication becomes a channel to send a message or stimulus to get a certain response. Communication is also a process of 
attention becoming a memory, and communication itself has the goal to encourage the birth of a behavior [9].

\subsection{Culture}

Bahri \& Subhandi stated culture as a set of attitudes, beliefs, behaviors, and also values owned by a group of individuals, where a set is communicated from one generation to the next generation, the way on how to communicate that set can be done through language or by other means of communication [10].

Culural differences certainly have negative side as well as positive side. According to Nasrullah on the positive side, cultural differences can give their own characteristics to a group or society, on where these characteristics can help a group to be distinguished from other groups. In addition, a culture can also make a strong bond between the members of the group. But on the contrary, cultural differences can also give a negative impact. As example, conflict may happen between individuals or groups in a communication process. So, it is very important for us to understand that communication may give an impact on a good culture and interaction [11].

\subsection{Theory of Acculturation \& Culture Shock}

The Theory of Acculturation was first introduced by Berry in 1987, while cultural shock was introduced by Oberg in 1960. According to Koentjaraningrat, the concept of acculturation is a social process, the process occurs when a group of individuals who already have their own culture is faced with a foreign or new culture [12].

Berry identifies acculturation into four models, which are: (1) Assimilation, when the individual loses the original culture that he has, and gers a new identity from his host culture. (2) Integration, occurs when the individual maintains the original culture that he has, when he is interacting with his host culture. (3) Separation, the model in which the individual chooses to interact with the host culture at a low level. In this model the individual prefers a closed relationship and reaffirms the culture he has. (4) Marginalization, occurs when the individual prefers not to identify either the indigenous culture he has and the host culture [13].

Oberg uses the term culture shock to describe the deep and negative response faced by a person, the personal consequences of him obliged to stay in a new environment, which he has never met before [14]. Mulyana stated culture shock as a clash of perceptions that occur because of the use of someone's perception based on several internal factors (cultural values) which have been studied with different cultural values and not understanding the new or different values [15]

Utami stated that cultural shock can be described as a curve, commonly referred as the "U Curve Hypothesis". Where this curve is initiated by positive feelings, such as optimism and excitement, but will eventually run on negative feelings, such as frustration, tension and anxiety, which happens because the individual can't have a good and effective interaction with the new environment and culture which they face. According to Utami to live in two cultures, namely the original culture that a person has and the new culture he faces, an individual must try to adapt again to the culture he had before.This eventually gave birth to the idea of the W Curve, which was a combination of the two U Curves. When someone returns to their hometown after a long stay in a foreign culture, they will again experience the phenomenon of cultural shock, but the difference this time is they will try to re-adapt to the original culture they have. For example, students who return after studying in another country will have different perspectives and see the world from different perspectives too [16].

\subsection{Inter-Cultural Communication}

According to Cheristien \& Susanto a group can be distinguished from other groups through the communication that the members have [17]. In addition, Bahri \& Subhandi stated that communication behavior is part of cultural and subcultural behavior within a group. A culture can influence the way of an individual to communicate [18].

Liliweri stated that inter-cultural communication can be done if the communicator or messenger comes from a culture and the communicant or recipient of the message also comes from another culture. Inter-cultural communication is a process of exchanging messages or meanings, whereas the meaning is in the form of symbols, and this process is carried out by two individuals who have different cultural backgrounds [19]. According to Susanto basically similarities in culture can create a good and smooth communication path, while on the contrary side differences in culture can lead to a line of communication that is not smooth and full of challenges [20].

\section{METHODS}

In this study the authors used an approach with qualitative methods. Qualitative research is a research method that can be used by researchers to examine the condition of a natural object, in this method researchers act as a key instrument. In addition, researchers will use phenomenological research methods. Researchers use phenomenological methods to determine the phenomenon of cultural shock experienced by students who have studied in Taiwan and then returned to Indonesia, where through this study researcher will examine an awareness of the experiences that have been passed by the study subjects. In this study, researchers will select several individuals who have studied in Taiwan as the subject of research. There are also several criteria that researchers have determined for informants, which are: (1) Have studied in Taiwan for several years, (2) Have returned to Indonesia to stay, (3) Experiencing cultural shock while re-adapting in Indonesia. In addition, the object of the 
research conducted by researchers here is the phenomenon of cultural shock that occurs when Indonesian students who have become accustomed to Taiwanese culture must return to Indonesia and be confronted again with Indonesia culture.

\section{FINDINGS AND DISCUSSIONS}

Taiwan is one of the countries that is quite in demand by students to travel and study. After they have finished studying in other countries, of course the students will return to their own country. And since they have not met and interacted with Indonesian culture for a long time, it will make them not used to Indonesian culture because they are used to Taiwanese culture. This illustrates the Model of Assimilation in The Theory of Acculturation, in which the students have lost their original culture, namely Indonesian culture, and have gained a new identity from the new culture they encountered, namely Taiwanese culture.

When these students re-enter Indonesian culture, it is natural for them to experience various pressures or difficulties. The pressures or difficulties occur because the students were used to the things that had been around him before, namely Taiwanese culture. Oberg uses the term culture shock to describe the profound and negative responses faced by a person, the personal consequences of having to settle in a new environment, which he has never met before [21].

Cultural shock can be described as a curve, commonly referred to the "U Curve Hypothesis". Where this curve is initiated by positive feelings, such as optimism and excitement, but will eventually run on negative feelings, such as frustration, tension and also anxiety, this happens because the individual cannot make good and effective interactions with the new environment and culture they face [22].

This U curve describes four levels, which are: (1) Optimistic, Phase as the first phase experienced by someone. This first phase is filled with pleasure, hope, and euphoria as an anticipation of the individual as it enters into a new culture. (2) Cultural, problems where the individual begins to experience problems with the new environment and culture he encounters, such as difficulties in the language. (3) Recovery, phase where the individual gradually and slowly begins to adjust and modify the way he uses in tackling the new culture he faced. At this stage the individual begins to feel less depressed anymore. (4) Adjustment, Phase as the last phase of the U Curve. At this stage the individual already understands the key elements of the new culture that he faced, those elements are beliefs, communication patterns, values embraced, and many else [23].

To live in two cultures, the original culture that a person has and the new culture he is facing, an individual must try to adapt again to the culture he had before. This eventually gave birth to the idea of the $\mathrm{W}$ Curve, which was a combination of the two U Curves. When the students return to Indonesia after a long stay in Taiwanese culture, they will again experience the phenomenon of cultural shock, but the difference here is this time they will try to re-adapt to their original culture.

Researchers will discuss the differences and difficulties that students experience, as well as how they handle these difficulties when they return to Indonesia.Here are the results of the research conducted:

\subsection{Differences Between Indonesian \& Taiwan Culture}

There are some striking differences between the culture and customs of Taiwanese and Indonesian people. The first difference is discipline, according to our interviewees, Taiwanese are more discipline than the Indonesian. Taiwanese dare to rebuke if someone violates the rules. In addition, neatness in the marches is also one of the things that describe discipline in Taiwan. There are still some Indonesians who like to stifle when marching, besides that the march in Indonesia is also messier when compared to Taiwan.

The next difference is in cleanliness, according to the interviewees, Taiwanese have a better level of cleanliness compared to Indonesian. Where they think there are still many people in Indonesia who like to litter. From the results of the interview, researchers looked at several factors that cause this, the first is that in Taiwan there are CCTV on every corner of the street, so that if someone litters, it can be caught by CCTV and will be fined. In addition, in Taiwan we can find trash cans everywhere and making it easier for us to dispose the waste. And the last is that the Government of Taiwan established a well-established recycle policy, in which the Taiwanese government runs the 4-in-1 Recycling Program.

The third difference is in terms of dressing, according to the interviewees, the way on how Taiwanese dressed are more flexible when compared to Indonesia. And the last difference is in the aspect of food, according to the interviewees, food in Taiwan seems blander when compared to Indonesian food. In addition, Taiwanese diet is also healthier than Indonesian, this is due to the healthy lifestyle of Taiwanese people.

\subsection{Difficulties in Transportation \& Communication}

Transportation becomes a difficulty for students who have returned to Indonesia. According to the interviewees, transportation in Taiwan is more accessible when compared to Indonesia. This certainly causes difficulties for those, who are used to the convenience of public transportation in Taiwan. According to the interviewees, public transportation in Taiwan is more comfortable and safer when compared to Indonesia. In addition, traffic jams in Jakarta are also one of the difficulties experienced by the speakers. According to the $\mathrm{s}$ interviewees, this makes it difficult for them to do their activities. 
Another difficulty felt by the interviewees is in the aspect of communication. Because they are used to using Mandarin, the interviewees often accidentally use Mandarin when communicating with people around them in Indonesia. The first factor that causes this difficulty is the lack of knowledge of the words in Bahasa Indonesia. Many of the interviewees state that they do not know the word in Bahasa Indonesia, especially if the word is less used in everyday life. In addition, they also know less about shorthand or trendy words that are commonly used by young children.

The next factor is a lack of understanding in using the correct sentence structure. Due to the different use or placement of Taiwan and Indonesia sentences, the interviewees have difficulty in building a sentence. The third factor is the difference in point of view and also the topic of discussion in the people of Indonesia and Taiwan. A topic may be considered normal if discussed from a Taiwanese point of view, but it may be sensitive for Indonesian. This difficulty will certainly lead to ineffective communication, where what the communicator conveys, is not well received by the communicant.

\subsection{Overcoming the Phenomenon of Culture Shock}

From the results of the interview, it can be seen that age is one of the factors that can determine how quickly someone is adapting to a culture. The younger a person is, the easier it is for him to adapt to a new culture. The interviewees found it more difficult adapting Indonesian culture today rather than when adapting to Taiwanese culture when they were still at an early age.

One way that can help us adapt to a culture is to conduct intercultural communication. According to the interviewees, increasing friendships with Indonesian friends can help them to adapt to Indonesian culture. Through interaction and communication, we can get to know a culture better. According to the interviewees, when interacting with their Indonesian friends, they can learn and imitate the habits of their friends.

In addition, the existing technology nowadays can also help us adapting to a culture. When we are confused or do not understand a culture, we can directly look for it on the internet through our gadgets. As an example, when we do not understand a word, we can easily search for its meaning through the Internet. In adapting to a culture, we need to remember the most important thing is that we should not be thinking is "only our culture is right, other else are wrong or not good". Each culture certainly has its own uniqueness.

\section{CONCLUSIONS}

The conclusions in this research are there are four differences that are quite significant between Taiwan and Indonesia, the first is the cleanliness in a cleaner environment, the way on how people dress, and the last is the food. Besides, students who have just returned to
Indonesia have difficulty in transportation and communication aspects. Where Taiwan public transportation is more convenient and accessible. And communication difficulties themselves are caused by several factors, namely there are many words that are poorly understood, lack of understanding within the sentence structures, and differences in viewpoints and topics of conversation. And there are two ways that can help a person to adapt to a culture which are increasing interaction with the people of that culture.In addition technology and the internet can also help people adapting to a new culture.

\section{ACKNOWLEDGMENT}

This work was supported by Faculty of Communication University Tarumanagara, Jakarta 11440, Indonesia, and International Conference of Economics, Business, Social, and Humanities (ICEBSH) 2021.

\section{REFERENCES}

[1] Soemantri, Nathalia Perdani. Adaptasi Budaya Mahasiswa Asal Indonesia di Australia, 2019, pp. 52.

[2] Susanto, Eko Harry. Komunikasi Politik: Pesan, Kepemimpinan, \& Khalayak, Jakarta: Mitra Kencana Media, 2013, pp. 21.

[3] Nurfirdaus, Nunu., \& Risnawati. Studi Kasus Pembentukan Kebiasaan Dan Perilaku Sosial Siswa, Volume 4 No. 1, 2019, pp. 38.

[4] Rachma, Ayu Siti. Studi Fenomena Gegar Budaya Mahasiswa Asal Sumatera di Untirta, 2016.

[5] Rohma, Rini Andriani. Studi Kasus Gegar Budaya Mahasiswa Afirmasi Papua di Universitas Pendidikan Indonesia, 2016.

[6] Lestari, Jessica., \& Sinta Paramita. Hambatan Komunikasi dan Gegar Budaya Warga Korea Selatan yang Tinggal di Indonesia, Journal of Communication Sciences from Tarumanagara University, 2019.

[7] Utami, Lusia Savitri Setyo. Teori-Teori Adaptas Antar-Budaya, Journal of Communication Sciences from Tarumanagara University, Volume 7 No. 2, 2019.

[8] Liliweri, Alo. Komunikasi Antar-personal, Jakarta: Premadamedia Group, 2017, pp. 3. 
[9] Susanto, Eko Harry. Komunikasi Manusia Esensi dan Aplikasi dalam Dinamika Sosial Ekonomi Politik, Jakarta: Mitra Kencana Media, 2010, pp. 4.

[10] Bahri, Rinjani., \& Subhandi. Komunikasi Lintas Budaya, Sulawesi: Unimal Press, 2017, pp. 1.

[11] Nasrullah, Rusli. Komunikasi Antar Budaya: di Era Budaya Siber, Jakarta: Kencana, 2012, pp. 19.

[12] Azeharie, Suzy. Pola Komunikasi Antar Pedagang dan Pembeli di Desa Pare, Kampung Inggris Kediri, Journal of Communication Sciences from Tarumanagara University, Volume 9 No 2, 2015, pp. 214.

[13] Utami, Lusia Savitri Setyo. Teori-Teori Adaptas Antar-Budaya, Journal of Communication Sciences from Tarumanagara University, Volume 7 No. 2, 2019, pp. 191.

[14] Devinta, Marshellena., Hidayah, Nur., \& Hendrastomo, Grendi. Fenomena Culture Shock (Gegar Budaya) Pada Mahasiswa Perantau di Yogyakarta, 2015, pp. 3.

[15] Mulyana, Deddy., \& Rakhmat, Jalaluddin. Komunikasi Antarbudaya: Panduan Berkomunikasi Dengan Orang-Orang Berbeda Budaya, 2009, pp. 24.

[16] Utami, Lusia Savitri Setyo. Teori-Teori Adaptas Antar-Budaya, Journal of Communication Sciences from Tarumanagara University, Volume 7 No. 2, 2019, pp. 191-192.

[17] Cheristien, Veranica., \& Susanto, Eko Harry. Pergeseran Makna Perayaaan Tahun Baru Imlek Bagi Etnis Tionghua di Jakarta, Journal of Communication Sciences from Tarumanagara University, Volume 3 No. 1, 2019, pp. 153.

[18] Bahri, Rinjani., \& Subhandi. Komunikasi Lintas Budaya, Sulawesi: Unimal Press, 2017, pp. 29.

[19] Suryandari, Nikmah. Komunikasi Lintas Budaya, Surabaya: Putra Media Nusantara, 2019, pp. 12.

[20] Susanto, Eko Harry. Komunikasi dan Gerakan Perubahan: Kemajuan Dalam Konstelasi Sosial, Ekonomi, Politik, Jakarta: Mitra Kencana Media, 2016, pp. 27.

[21] Devinta, Marshellena., Hidayah, Nur., \& Hendrastomo, Grendi. Fenomena Culture Shock (Gegar Budaya) Pada Mahasiswa Perantau di Yogyakarta, 2015, pp. 3.
[22] Utami, Lusia Savitri Setyo. Teori-Teori Adaptas Antar-Budaya, Journal of Communication Sciences from Tarumanagara University, Volume 7 No. 2, 2019, pp. 191.

[23] Devinta, Marshellena., Hidayah, Nur., \& Hendrastomo, Grendi. Fenomena Culture Shock (Gegar Budaya) Pada Mahasiswa Perantau di Yogyakarta, 2015, pp. 4. 